\title{
Det farlige bukfettet
}

Normalvektige med mye fett rundt midjen har større risiko for hjerteog karsykdommer enn normalvektige med lite bukfett, ifølge ny studie.

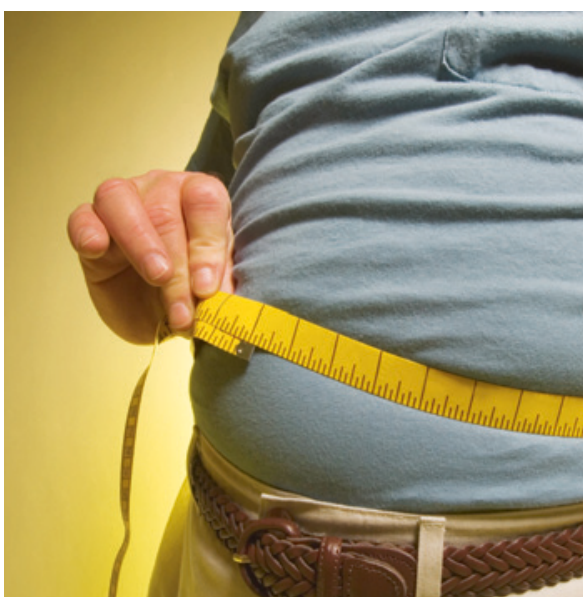

Illustrasjonsfoto: Thinkstock
Kroppsmasseindeks alene sier lite om risikoen for utvikling av hjerte- og karsykdom. Flere studier har vist at fordelingen av kroppsfettet er viktig. Mål som midjeomkrets og midje-hofte-ratio brukes i økende grad for å vurdere slik risiko.

I en amerikansk studie (1) fylte flere enn 15000 voksne ut et spørreskjema og ble undersøkt klinisk. Midje-hofte-ratio ble brukt som mål på mengden bukfett. Pasientene ble gjennomsnittlig fulgt i 14,3 år. Totaldødeligheten var høyere hos dem med høy midjehofte-ratio og normal kroppsmasseindeks enn hos dem med normal midje-hofte-ratio og samme kroppsmasseindeks. Menn med en kroppsmasseindeks på $22 \mathrm{~kg} / \mathrm{m}^{2}$ og høy midje-hofte-ratio hadde 1,87 ganger høyere dødelighet $(95 \%$ KI 1,53-2,29) enn menn med en kroppsmasseindeks på $22 \mathrm{~kg} / \mathrm{m}^{2} \mathrm{og}$ normal midje-hofte-ratio. Tilsvarende risiko hos kvinner var på 1,48 (95\% KI 1,35-1,62).

- At høy midje-hofte-ratio hos normalvektige kan være assosiert med økt risiko for prematur død, understøtter forskning som har vist at bukfett er farligere enn under- hudsfett på rumpe og lår, sier Jøran Hjelmesæth, som er professor ved Universitetet i Oslo. - Seleksjonsskjevhet og invers kausalitet kan imidlertid ikke utelukkes, sier han.

- Hovedresultatet i studien er basert på forfatternes egne definisjoner av sentral fedme, og disse er ikke i tråd med internasjonale retningslinjer. Midjens omkrets ble heller ikke målt $\mathrm{i}$ henhold til anerkjente kriterier. Disse svakhetene gjør at resultatene ikke kan generaliseres eller implementeres i klinisk praksis, sier Hjelmesæth.

\section{Kaveh Rashidi}

Tidsskriftet

\section{Litteratur}

1. Sahakyan KR Somers VK, Rodriguez-Escudero JP et al. Normal-weight central obesity: implications for total and cardiovascular mortality. Ann Intern Med 2015; 163: 827-35.

\section{Smertebehandlingen i akuttmottak er ikke god nok}

\author{
Vurdering og behandling av smerte i norske akuttmottak er utilfredsstil- \\ lende og følger ikke lokale retningslinjer. Det viser en ny studie.
}

Smerte er en av de vanligste årsakene til at man oppsøker akuttmottaket. Tidligere studier har vist at mange pasienter ikke får tilstrekkelig smertebehandling der.

I en nylig publisert studie ønsket man å undersøke om smertevurdering og smertebehandling i akuttmottak var i samsvar med sykehusets retningslinjer (1). Studien omfattet 764 pasienter.

Hos $23 \%$ av pasientene ble det ikke gjort noen smertevurdering. Av de øvrige 586 pasientene som ble vurdert med Numerical Rating Scale (NRS), hadde 226 (39\%) moderat eller alvorlig smerte, definert ved en NRS-verdi $>3$. Disse pasientene skulle i følge de lokale retningslinjene ha smertebehandling i akuttmottaket, men bare 32 (14\%) fikk slik behandling.

- Denne studien ser ut til å bekrefte at smertebehandlingen i norske akuttmottak ikke er god nok, sier Sven Erik Gisvold, professor emeritus i anestesiologi ved St. Olavs hospital. - Men jeg savner flere data og opplysninger som ville ha styrket konklusjonene. Jeg skulle gjerne ha sett en tabell med dia- gnose og lokalisering av smerten som ble bedømt versus ikke bedømt og hos dem som faktisk ble behandlet, og hvor intens smerten var i de ulike undergruppene. Likeledes savnes data om faktorer som kan vanskeliggjøre bedømmelsen og kanskje delvis forklare hvorfor personellet var tilbakeholdne, slik som mental status, bruk av rusmidler, ustabil fysiologisk tilstand, mulighet for overvåking, overfylt akuttmottak etc. Det burde også ha vært en tabell med resultater av smertebehandlingen, som ifølge metodebeskrivelsen skulle bedømmes, og en diskusjon om mulige årsaker til at vurdering og behandling av smerte ikke var optimal. Det kan være mange grunner til det, både medisinske og organisatoriske, sier Gisvold.

\section{Liv-Ellen Vangsnes}

Tidsskriftet

1. Dale J, Bjørnsen LP. Assessment of pain in a Norwegian emergency department. Scand J Trauma Resusc Emerg Med 2015; 23: 86.

\section{Litteratur}

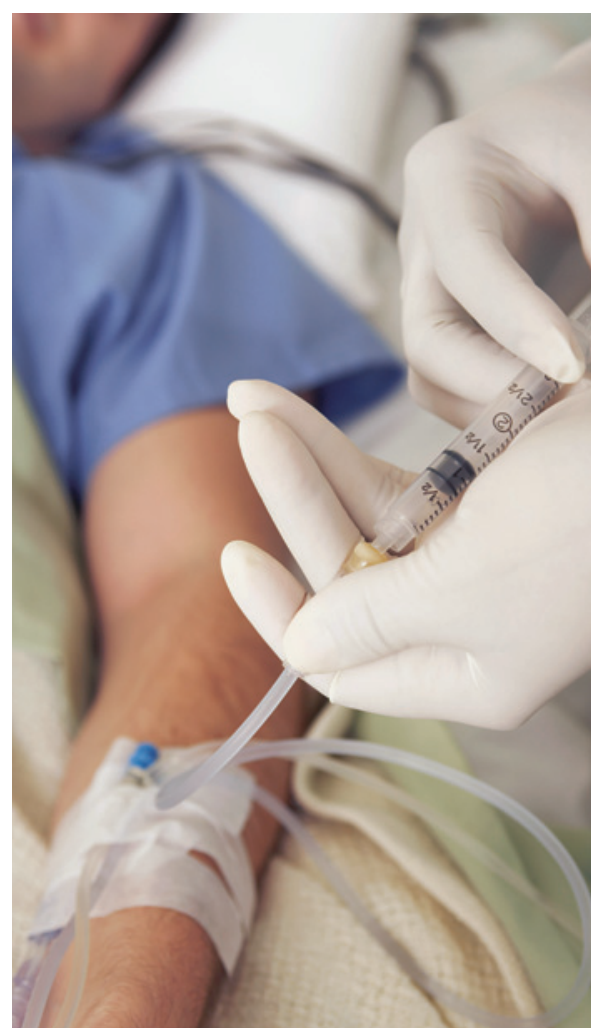

Illustrasjonsfoto: NTB scanpix 